Article

\title{
Study of Ecophysiological Responses of the Antarctic Fruticose Lichen Cladonia borealis Using the PAM Fluorescence System under Natural and Laboratory Conditions
}

\author{
Sung Mi Cho ${ }^{1}\left(\mathbb{D}\right.$, Hyoungseok Lee ${ }^{2,3} \mathbb{0}$, Soon Gyu Hong ${ }^{2}$ and Jungeun Lee ${ }^{1, *} \mathbb{C}$ \\ 1 Unit of Research for Practical Application, Korea Polar Research Institute, Incheon 21990, Korea; \\ smcho@kopri.re.kr \\ 2 Division of Polar Life Sciences, Korea Polar Research Institute, Incheon 21990, Korea; \\ soulaid@kopri.re.kr (H.L.); polypore@kopri.re.kr (S.G.H.) \\ 3 Polar Sciences, University of Science and Technology, Daejeon 34114, Korea \\ * Correspondence: jelee@kopri.re.kr; Tel.: +82-32-760-5576
}

Received: 14 October 2019; Accepted: 7 January 2020; Published: 9 January 2020

\begin{abstract}
Antarctic lichens have been used as indicators of climate change for decades, but only a few species have been studied. We assessed the photosynthetic performance of the fruticose lichen Cladonia borealis under natural and laboratory conditions using the PAM fluorescence system. Compared to that of sun-adapted Usnea sp., the photosynthetic performance of $C$. borealis exhibits shade-adapted lichen features, and its chlorophyll fluorescence does not occur during dry days without rain. To understand its desiccation-rehydration responses, we measured changes in the PSII photochemistry in C. borealis under the average light intensity of dawn light and daylight and the desiccating conditions of its natural microclimate. Interestingly, samples under daylight and rapid-desiccation conditions showed a delayed reduction in $F v^{\prime} / F m^{\prime}$ and rETRmax, and an increase in $\mathrm{Y}(\mathrm{II})$ and $\mathrm{Y}(\mathrm{NPQ})$ levels. These results suggest that the photoprotective mechanism of $C$. borealis depends on sunlight and becomes more efficient with improved desiccation tolerance. Amplicon sequencing revealed that the major photobiont of $C$. borealis was Asterochloris irregularis, which has not been reported in Antarctica before. Collectively, these results from both field and laboratory could provide a better understanding of specific ecophysiological responses of shade-adapted lichens in the Antarctic region.
\end{abstract}

Keywords: fruticose lichens; Cladonia borealis; Antarctic; phytochemistry; poikilohydric; nonphotochemical quenching; desiccated state; shade-adapted lichen

\section{Introduction}

Antarctic climates are extremely cold, with high irradiation and strong winds, and therefore, the photosynthetic organisms in this area experience repeated desiccation-rehydration conditions [1-3]. Antarctic vegetation is mainly composed of the poikilohydric organisms, mosses and lichens $[4,5]$. Poikilohydry is accompanied by the ability to survive in a desiccated state (below $10 \%$ relative humidity) for long periods [1-3], which allows these organisms to inhabit extreme environments, such as desert, the Arctic, and Antarctic ecosystems where vascular plants fail to adapt [6-8].

Two mechanisms have been reported for desiccation tolerance in photosynthetic organisms, which are a delay in the rate of water loss and rapid repair after desiccation [9]. The former, which usually occurs in vascular plants, extends the time required for dehydration by days or even weeks and focuses on protecting against desiccation damage $[10,11]$. In contrast, the latter operates in nonvascular 
plants including algae, bryophytes, and lichens, and works efficiently to restore respiration and photosynthesis within a few minutes after rapid desiccation (RD) of less than $1 \mathrm{~h}[9,12]$. As prolonged desiccation-rehydration cycles concomitantly produce reactive oxygen species (ROS) in the chloroplast and mitochondria, photobionts especially must also develop photoprotective machinery $[13,14]$. Thermal dissipation during desiccation is an effective photoprotection mechanism because the rate of heat dissipation is faster than its usage for photochemistry in the reaction center or for fluorescence emission [15-17]. Thermal dissipation progress called 'non-photochemical quenching (NPQ)' is known to prevent, to some extent, ROS formation induced by photooxidative damage using different carotenoids and the reversible xanthophyll cycle.

As lichens are complex symbiotic organisms consisting mainly of mycobionts (fungi) and photobionts (algae and/or cyanobacteria), the NPQ response of each lichen species could also vary due to interactions between the mycobionts and photobionts and/or others symbiotic organisms. Indeed, the NPQ responses of several lichens are differentially regulated by solar irradiation (intensity and duration) and the extent of desiccation. A seasonal variation study revealed that NPQ positively associates with solar irradiation in Lobaria pulmonaria [18,19]. In other cases, NPQ was shown to increase when the water content was reduced in Parmelia quercina [20], or it was maintained in Ramalina maciformis and Cladonia vulcani via a de-epoxidation reaction of the xanthophyll cycle under desiccation [21,22]. Although it is necessary to understand physiological responses during the NPQ process at the molecular level, the previously mentioned studies have indicated that lichens can have species-specific physiological responses, which probably are adaptations to their habitat.

In recent decades, lichens have been widely used in environmental monitoring, especially to study the effect of air pollution; however, their role as a bio-indicator reflecting climate changes in the Antarctic region was recently reassessed [23,24]. Approximately 400 species of lichens reside on dry and rocky surfaces rather than in wet habitats in the Antarctic Peninsula [24]. Members of the lichen genus Usnea are distributed across most dry habitats of Antarctica and have been used to investigate ecophysiology, antioxidant production, and photoinhibition responses and in long-term and short-term monitoring studies [23-28]. In U. antarctica, for example, their growth rate is strongly correlated with mean summer temperature changes, and photoinhibitory quenching (qI)—a component of NPQ - mainly works to protect photosystems from high light intensity $[23,24,26,27]$. In addition, a low NPQ response is consistent with the finding that a small amount of glutathione is induced by high light levels, indicating that $U$. antarctica is likely to produce secondary compounds to protect against excess light [28].

Antarctic Usnea species have been extensively studied for several decades and are widely accepted as a model of Antarctic lichens. However, to understand the effects of climate change over the years, it is necessary to find other fruticose lichens with more sensitive photosynthetic performance. One candidate is Cladonia, a fruticose lichen genus, with 11 species on King George Island and 27 species reported throughout Antarctica [29-32]. Cladonia borealis S. Stenroos is found in the polar regions of both hemispheres and the alpine regions of the Andes Mountains [31,33,34], and it is one of the dominant species of Antarctic vegetation [35-37]. To date, studies on C. borealis have focused on its taxonomy, the genetic recognition of mycobiont and photobiont diversity, evolutionary history, and geographical distribution [35,37-39]. However, there have been no ecophysiological studies on this species focusing on its photosynthetic response to microclimate changes.

In this study, we assessed the photosynthetic performance of C. borealis compared to that of Usnea sp. in response to microclimate changes under field conditions. In addition, to understand how $C$. borealis responds to desiccation-rehydration, we examined changes in PSII photochemistry under controlled laboratory conditions. We also analyzed major photobionts of this lichenized fungus by amplicon sequencing. We used the results of field and laboratory experiments to discuss the utility of C. borealis for biomonitoring the effects of climate change in the Antarctic region. 


\section{Results and Discussion}

\subsection{Site Description and Lichen Identification}

The study site (KGL01: $62^{\circ} 14^{\prime} 24^{\prime \prime} \mathrm{S}, 58^{\circ} 44^{\prime} 36^{\prime \prime} \mathrm{W}$, at an altitude of $39 \mathrm{~m}$ ) is a windy hill front at the seashore near Potter Cove in Barton Peninsula, King George Island (Figure 1a). The mean annual temperature and rainfall are $-1.1^{\circ} \mathrm{C}$ and $42.8 \mathrm{~mm}$, respectively. In the summer season from December to February, the average temperature is $2.1^{\circ} \mathrm{C}$ with an average accumulated rainfall of $27.3 \mathrm{~mm}$, which is lower than the annual average rainfall (Figure S1). The site is an area where various lichens and moss species appear and are supplied with water from melted snow, rainfall, or dewfall. This area also appears to have different vegetation depending on the water gradient generated by a stream. The vegetation around the resulting pond can be divided into two parts based on color (Figure 1b). The golden and brown parts, which appear closer to the pond, are areas dominated by mosses-Sanionia uncinata and Chorisdontium aciphyllum, which grow in a carpet-shape-and lichens consisting of the genera Cladonia, Psoroma, and Ochrolechia [35,37]. The grey part, the dry area, is largely covered by species of the genus Usnea. C. borealis is mainly distributed in the area spanning the brown and grey parts; the mature shape of this species has a stalk that is $3-5 \mathrm{~cm}$ tall and $1-2 \mathrm{~cm}$ in diameter, with an upper cortex that forms a curved cover (Figure 1c) [32,36].
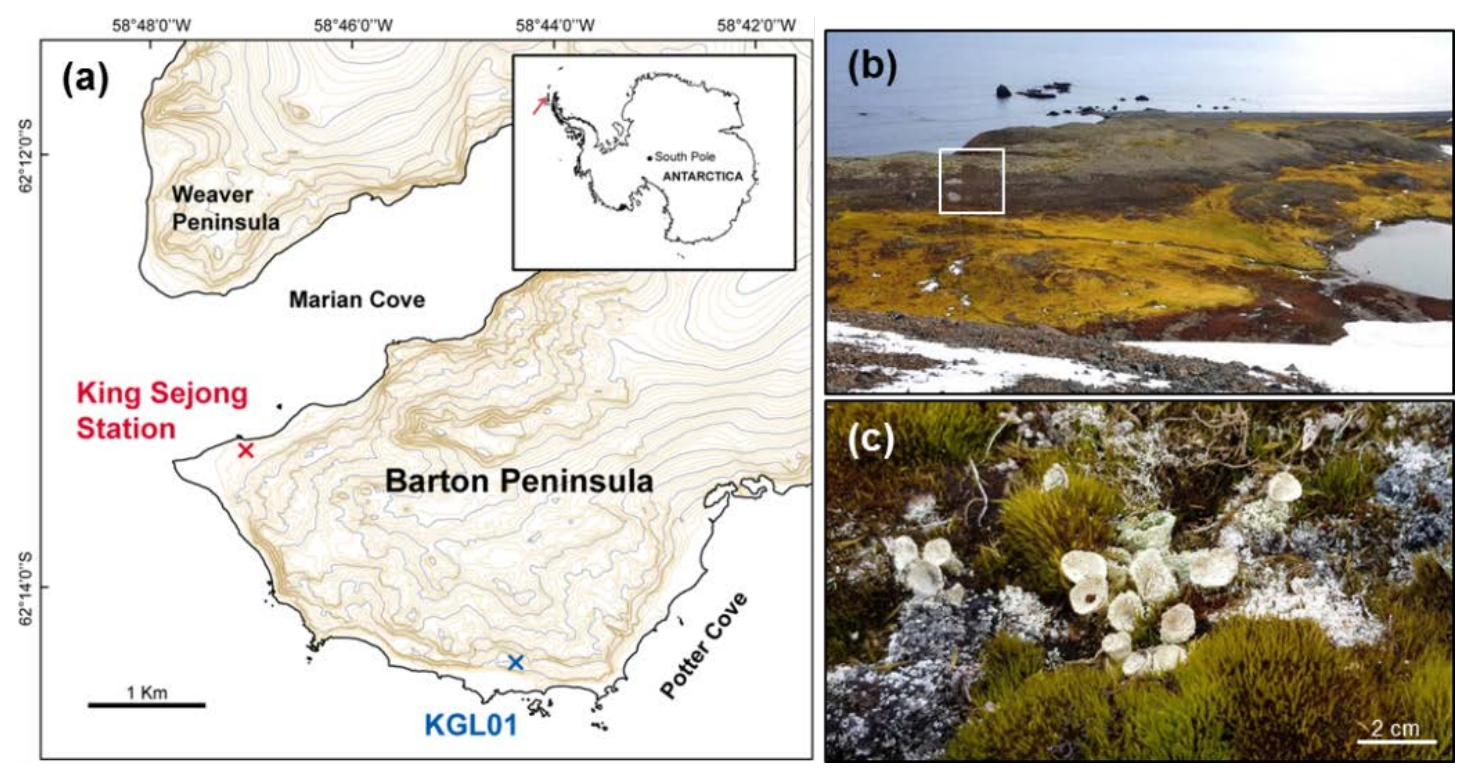

Figure 1. Location and landscape of the study site (KGL01: $62^{\circ} 14^{\prime} 24^{\prime \prime}$ S, $58^{\circ} 44^{\prime} 36^{\prime \prime} \mathrm{W}$ ), and an image of C. borealis at the field. (a) KGL01 on the map, placed near Potter Cove in Barton Peninsula. (b) This site has well-distinguished vegetation that consists of mosses and lichens. The area spanning the brown and grey parts was composed of lichens, and our observation was performed at the area indicated by the white box. (c) Several thalli of $C$. borealis accompanied by the moss Chorisdontium aciphyllum are shown.

The field survey to monitor the photosynthetic performance of $C$. borealis and the Usnea sp. was performed from 22-30 January 2019 (Figure 2). Microclimate factors such as photosynthetic photon flux (PPFD), air temperature $\left({ }^{\circ} \mathrm{C}\right)$, rainfall $(\mathrm{mm})$, and volumetric soil moisture $(\%)$ were also recorded. We identified our field samples as $C$. borealis based on the morphological and anatomical features described previously [36], and later confirmed by ITS sequencing. For lichen identification, fungal-specific ITS regions ( $900 \mathrm{bp}$ ) were amplified, sequenced, and identified as C. borealis (NCBI accession: DQ534459) with $98 \%$ query coverage, an $E$-value $=0$, and $99.3 \%$ identity. 


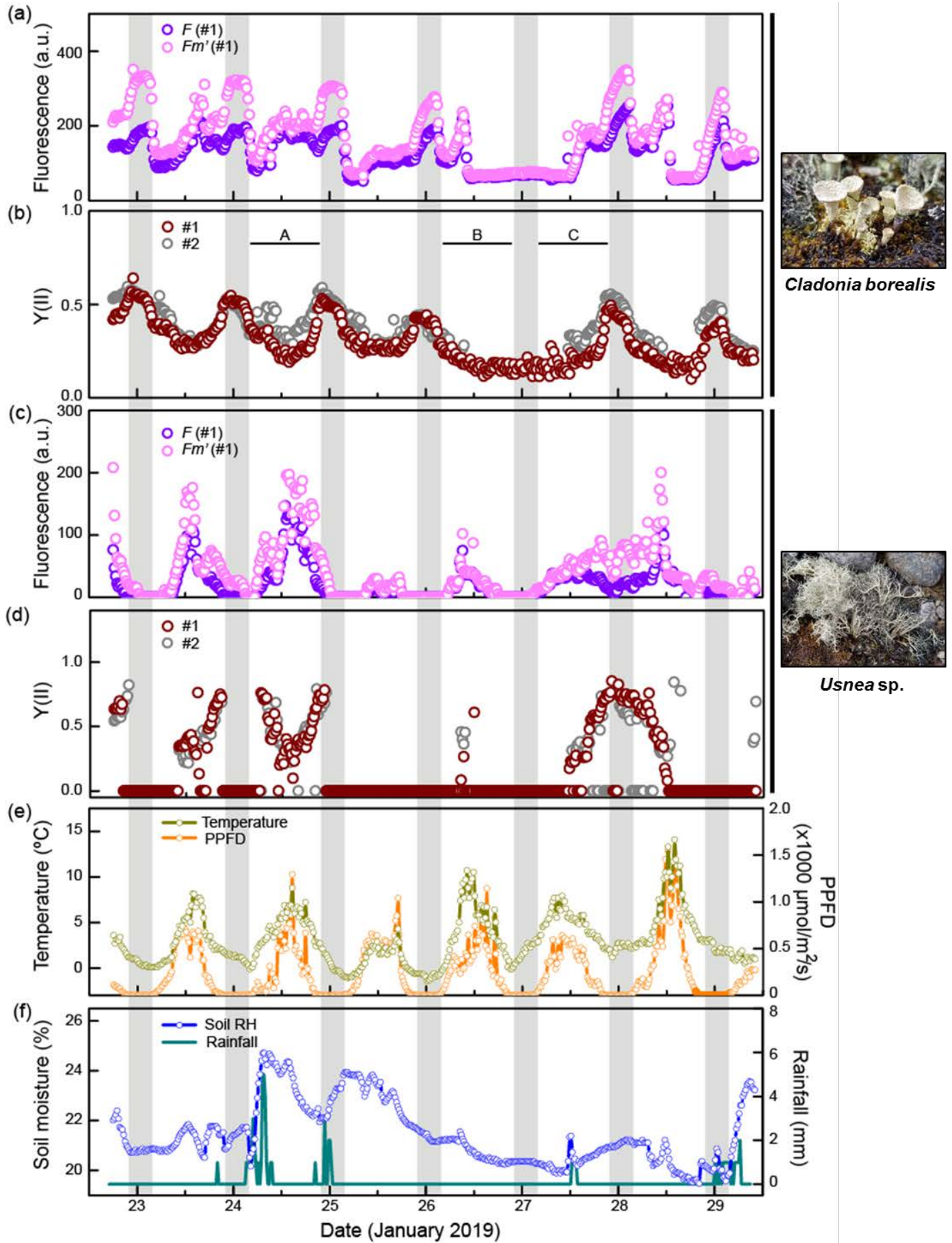

Figure 2. Field observation of the fluorescence $\left(F\right.$ and $\left.F m^{\prime}\right)$ and $Y(I I)$ value of $C$. borealis and Usnea sp. and microclimate at the site. Grey shading indicates nighttime (10 PM to 4 AM) when photosynthetic photon flux density (PPFD) was less than $10 \mu \mathrm{mol} / \mathrm{m}^{2} / \mathrm{s}$. (a,b) Fluorescence and Y(II) value of C. borealis (c,d) Fluorescence and Y(II) value of Usnea sp. Data were obtained from two individual thalli (Samples $\# 1, \# 2$ ). Patterns of fluorescence $\left(F\right.$ and $\left.F m^{\prime}\right)$ of $C$. borealis and Usnea sp. were similar between the two samples. (e) Changes in temperature $\left({ }^{\circ} \mathrm{C}\right)$ and PPFD $\left(\mu \mathrm{mol} / \mathrm{m}^{2} / \mathrm{s}\right)$. (f) Changes in volumetric soil moisture $(\%)$ and rainfall $(\mathrm{mm})$ during the observation period. F, current fluorescence; $\mathrm{Fm}^{\prime}$, maximum fluorescence. 


\subsection{C. borealis Photosynthetic Activity at Night and Dawn}

Nighttime was identified by a PPFD value less than $10 \mu \mathrm{mol} / \mathrm{m}^{2} / \mathrm{s}$; hence, the length of one night was approximately $6 \mathrm{~h}$ from $10 \mathrm{PM}$ to $4 \mathrm{AM}$ (Figure S2). During the observation period, temperature and PPFD changed with a diurnal rhythm. The temperature ranged from $-1{ }^{\circ} \mathrm{C}$ to $14^{\circ} \mathrm{C}$ and fell below $3{ }^{\circ} \mathrm{C}$ in the nighttime. Mean temperature during the daytime was $0.9^{\circ} \mathrm{C}$ to $6.0^{\circ} \mathrm{C}$, and the coldest day was on 25 January $\left(-1.1^{\circ} \mathrm{C}\right.$ to $\left.4.3^{\circ} \mathrm{C}\right)$. The mean daily PPFD value was generally $300-350 \mu \mathrm{mol} / \mathrm{m}^{2} / \mathrm{s}$, and the strongest irradiation was recorded on 28 January, with a mean value of $466 \mu \mathrm{mol} / \mathrm{m}^{2} / \mathrm{s}$ and a maximum of $1595 \mu \mathrm{mol} / \mathrm{m}^{2} / \mathrm{s}$ (Table S1; Figure 2e). Volumetric soil moisture ranged from 19.5 to $24.7 \%$. The mean value of soil moisture was higher, 21 to $23 \%$, on three days (23-25 January), but less than 21\% from 26-28 January. Accumulated rainfall was recorded every $10 \mathrm{~min}$, and total daily rainfall varied randomly. The most rain fell on 24 January $(60 \mathrm{~mm})$, followed by $18 \mathrm{~mm}$ on 25 January; for all other days, there was no rain or rainfall was less than $10 \mathrm{~mm}$ (Table S1; Figure 2f). We were unable to obtain data for the relative humidity $(\mathrm{RH})$ surrounding the lichens at that time; instead, we predicted the dryness based on records of both the volumetric soil moisture and rainfall events [40]. The fluorescence value represents the emission light intensity of chlorophyll a generated before $(F)$ and after $\left(F m^{\prime}\right)$ irradiation with a saturation pulse, and the difference between $F$ and $F m^{\prime}$ directly correlates with the effective photosynthetic yield, $\mathrm{Y}(\mathrm{II}): \mathrm{Y}(\mathrm{II})=\left(F m^{\prime}-F\right) / F m^{\prime}$ (Figure 2a-d) [41]. At a glance, the photosynthetic yield of the Usnea sp. showed a significant correlation $\left(\mathrm{R}^{2}>0.5\right)$ with PPFD and temperature, but not soil moisture; however, C. borealis showed less correlation (Table S2; Figure S3). In addition, the photosynthetic performance of $C$. borealis was quite different from that of the Usnea sp.

First, the maximum Y(II) value of $C$. borealis $(\sim 0.6)$ was lower than that of the Usnea sp. $(\sim 0.8)$, but the inactivation time of Y(II) in C. borealis $(12 \%, 57 / 491)$ was about six times shorter than that of the Usnea sp. $(69 \%, 340 / 490)$. The inactivation state of photosynthesis occurs when there is no difference between $F$ (present state) and $F m^{\prime}$ (maximum excitation capacity) values, meaning that the photosystems are not capturing photons. Inactivation occurs during photoinhibition or when the conditions for activation are insufficient. However, unlike the Usnea sp., the C. borealis photosynthetic performance was continuous and rhythmic in the Antarctic site (Figure 2).

There was a remarkable difference between the photosynthetic performances of the Usnea sp. and C. borealis across the three times of day: dawn (4:00-6:00), daytime (6:00-22:00), and night (22:00-4:00) (Table 1).

Table 1. Mean photosynthetic efficiency Y(II), PPFD, and temperature changes during dawn, daytime, and night. Numbers in parentheses indicate \pm standard deviation.

\begin{tabular}{cccc}
\hline & Night & Dawn & Daytime \\
\hline Time range & $22: 00-4: 00$ & $4: 00-6: 00$ & $6: 00-22: 00$ \\
Total data points & 133 & 42 & 316 \\
\hline PPFD $\left(\mu \mathrm{mol} / \mathrm{m}^{2} / \mathrm{s}\right)$ & $4( \pm 2)$ & $47( \pm 37)$ & $357( \pm 289)$ \\
Temperature $\left({ }^{\circ} \mathrm{C}\right)$ & $1.5( \pm 1.3)$ & $1.5( \pm 1.5)$ & $4.7( \pm 2.9)$ \\
\hline C. borealis & & \\
\hline $\mathrm{Y}(\mathrm{II})$ & $0.41( \pm 0.16)$ & $0.31( \pm 0.12)$ & $0.26( \pm 0.15)$ \\
Inactivation $(\%)$ & $7.1 \%$ & $7.1 \%$ & $14.1 \%$ \\
\hline Usnea sp. & \multicolumn{3}{c}{$0.19( \pm 0.25)$} \\
\hline Y(II) & $0.09( \pm 0.23)$ & $0.06( \pm 0.19)$ & $58.9 \%$ \\
\hline Inactivation $(\%)$ & $87.6 \%$ & $91.7 \%$ &
\end{tabular}

* Percent inactivation indicates the proportion of $Y($ III $=0$ in the total data points, because there is no difference between the $F$ and $F m^{\prime}$ values.

Photosynthetic activity of the Usnea sp. almost disappeared at night and dawn ( $90 \%$ inactivation), and was highest during the daytime, where activation was only $58 \%$. Photosynthetic performance of 
lichens generally increases $1-2 \mathrm{~h}$ after sunrise, and then rapidly decreases because high irradiation and an increase in temperature cause $\mathrm{CO}_{2}$ exchange to cease under the desiccating conditions [42]. Indeed, the growth rate of Usnea antarctica was sensitive to decreasing mean temperatures [23,24], and approximately $1000 \mu \mathrm{mol} / \mathrm{m}^{2} / \mathrm{s}$ light intensity was insufficient to induce photoinhibition [26,27]. Such photosynthetic features of Usnea sp. are probably associated with abundant inactivated states, which were observed in this study. In C. borealis, however, the mean Y(II) value was highest at night and gradually decreased from dawn to daytime. Low levels of inactivation were also observed at night and dawn ( $7 \%$ inactivation) and daytime ( $14 \%$ in Table 1$)$.

Lichens often are distinguished by their responses to light intensity (typically classified as sun- or shade-adapted species), which is associated with their habitat and secondary compound production $[43,44]$. Sun-adapted lichen species show no inhibition under high light levels; instead, they produce a secondary compound to screen out the light [45,46], and Usnea sp. have been reported to have this characteristic [26-28]. In contrast, shade-adapted lichen species show photoinhibition to strong light irradiation, and their maximum photosynthetic activity exists before noon if they have not undergone water stress $[40,47]$. Taken together, the photosynthetic performance of $C$. borealis indicates that it can be vigorously active even at low temperatures and in the dim light conditions of dawn and nighttime, suggesting that it has features of a shade-adapted lichen.

\subsection{Water Deficiency Is a Limiting Factor for Photosynthesis of C. borealis}

In this study, we successfully stimulated photosynthetic activity in response to microclimate changes in real time and showed how the photosynthetic efficiency of $C$. borealis is affected by microclimate changes. Interestingly, the Y(II) rhythm showed an irregular pattern in which night peaks were lost on the evening of 26 January, which was a dry day with low soil moisture; the most recent rainfall had been the night of 24 January. However, it rained the next afternoon, and the Y(II) had recovered by that night. To assess the effects of microclimate, we divided the observation period of Y(II) into three regions based on moisture conditions: wet (Region A, 24 January), dry (Region B, 26 January), and re-wetted (Region C, 27 January) (Figures 2b and 3). In Region A, the Y(II) value was strongly negatively correlated with PPFD and temperature, but not with soil moisture. The $Y($ II) in Regions B and C, however, appeared to be influenced by the low level of soil moisture and not by the diurnal rhythms of PPFD or temperature (Figure 3).

Although the low level of soil moisture was not directly related to the water content of C. borealis, the dramatic reduction in soil moisture and lack of rain from 25-26 January implied that the lichen was desiccated [40]. Furthermore, the strong correlation between $Y(I I)$ and soil moisture $\left(R^{2}>0.5\right)$ suggests that desiccation in C. borealis is a more limiting factor than high-light or low-temperature conditions.

We also found that the fluorescence dynamics of both lichen species were remarkably different during desiccation (Figure 2). In the Usnea sp., the fluorescence ( $F$ and $\left.F m^{\prime}\right)$ value during two days of desiccation (25-26 January) was dramatically lower than on 24 January, which was rather humid, and the Y(II) was eventually inactivated. Besides, Y(II) was completely inactive on 25 January, presumably due to the average temperature being $4{ }^{\circ} \mathrm{C}$. In $\mathrm{C}$. borealis, however, $\mathrm{Y}$ (II) was active until the soil moisture was below $\sim 21 \%$ at noon, indicating that $C$. borealis is more tolerant of desiccating conditions than the Usnea sp. From these observations, we expect that the photosystem II of C. borealis aggressively reacts to abiotic stresses in Antarctica using an effective photoinhibition process [48].

Lichens can absorb water from rain, fog, dew and air humidity [49-51], or substrate moisture [52], but, without rain, the water content of lichens is rapidly reduced via evaporation due to the high light intensity $[40,51,53]$. The fruticose form has the advantage of capturing water from the air because of its large surface area. However, the water retention ability differs depending on the specific lichen and its substrates. C. borealis thalli often grow close together, and they are commonly found on or near moss colonies. In contrast, Usnea species are usually found on rocks with spaces between them. Such substrate specificities and distribution patterns of thalli also greatly affect the acquisition of water from the air and the lichen's water retention ability $[40,54]$. 
(a)

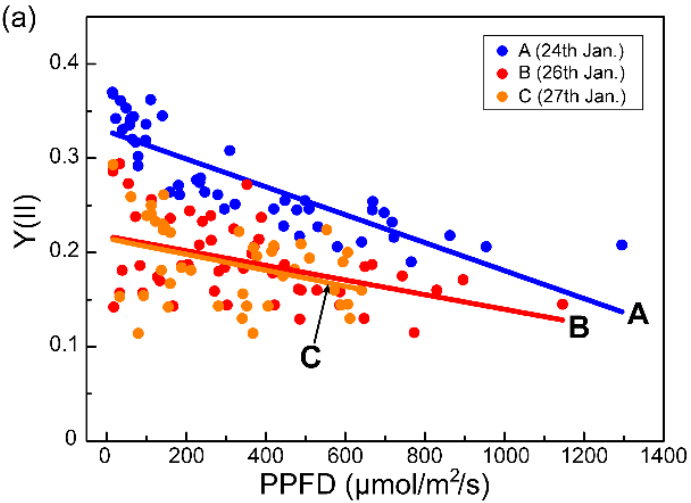

(c)

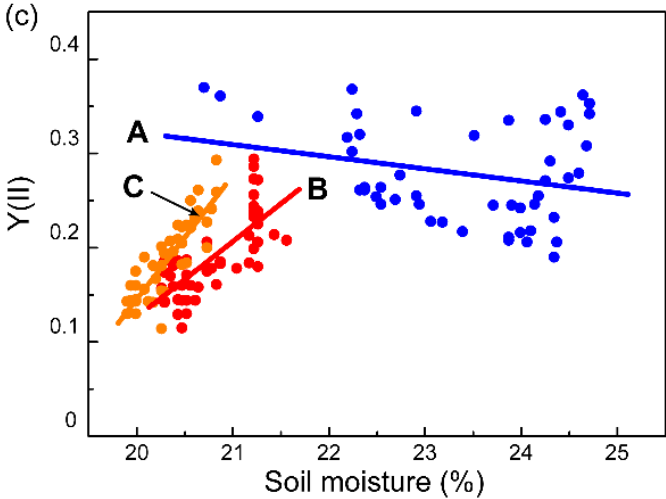

(b)

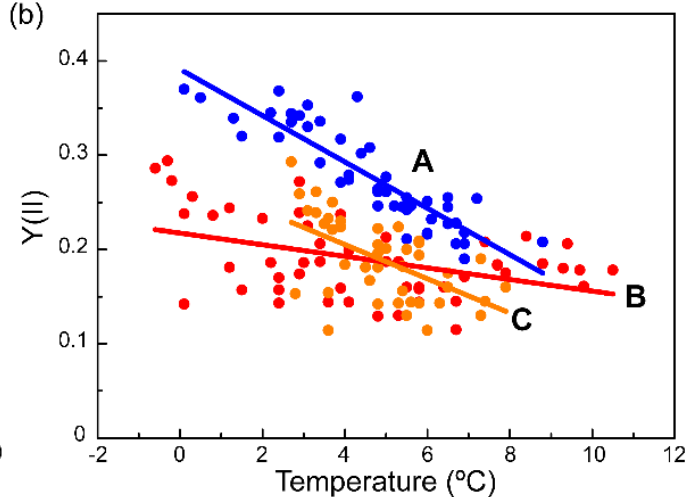

(d) Summary of linear regression analysis

\begin{tabular}{lcccl}
\hline Y(II) vs. & Region & Slop & SE & \multicolumn{1}{c}{$\mathrm{R}^{2}$} \\
\hline \multirow{4}{*}{ (a) PPFD } & A & $-1.48 E-4$ & $1.37 \mathrm{E}-5$ & $\mathbf{0 . 7 0 9 ^ { * }}$ \\
& $\mathrm{B}$ & $-7.76 \mathrm{E}-5$ & $2.14 \mathrm{E}-5$ & 0.195 \\
& $\mathrm{C}$ & $-8.45 \mathrm{E}-5$ & $3.28 \mathrm{E}-5$ & 0.120 \\
\hline \multirow{4}{*}{ (b) Temperature } & $\mathrm{A}$ & -0.024 & 0.001 & $\mathbf{0 . 7 8 4}$ \\
& $\mathrm{B}$ & -0.006 & 0.001 & 0.172 \\
& $\mathrm{C}$ & -0.018 & 0.004 & 0.300 \\
\hline \multirow{4}{*}{ (c) Soil moisture } & $\mathrm{A}$ & -1.286 & 0.705 & 0.047 \\
& $\mathrm{~B}$ & 8.031 & 0.996 & $\mathbf{0 . 5 6 1 *}$ \\
& $\mathrm{C}$ & 13.129 & 1.363 & $\mathbf{0 . 6 9 1}$ \\
\hline
\end{tabular}

Figure 3. Correlation between $Y($ II) of $C$. borealis and PPFD (a), temperature (b), and volumetric soil moisture (c) parameters. Data were extracted from Regions A, B, and C in Figure 2b. A fitting analysis for linear regression was performed for each dataset. (d) The linear regression parameters are presented in a tabular format. Asterisks indicate $\mathrm{R}^{2}>0.5$. SE, standard error.

In this study, we used the Monitoring-PAM system, which allows high-throughput data acquisition for several days to months in the Antarctic field. This system provides chlorophyll fluorescence parameters $\left(F\right.$ and $\left.F m^{\prime}\right)$ in minute intervals. In contrast with previous reports that had measurements every few hours $[45,55,56]$, this system provides real-time dynamics of photosynthetic performance in response to fluctuating environmental changes. From the data acquired in this study, we recognize that lichen species have different levels of photosynthetic performance sensitivity. Compared to the sun-adapted features of the Usnea sp., shade-adapted C. borealis has a highly susceptible photoinhibition process to protect against high light levels, low temperatures, and water-deficit conditions in its natural habitat. In addition, even small environmental changes can be a limiting factor in photosynthetic performance depending on the lichen species (Figures 2 and 3). Taken together, these chlorophyll fluorescence monitoring data in real-time indicate that there are still unknown, lichen-species-dependent ecophysiological responses to microclimate changes in their niches.

\subsection{Photoinhibition Response of C. borealis under a Laboratory Mimic of Microclimate Conditions}

The field monitoring results suggest that the photosynthetic performance of $C$. borealis is resistant to changes in light and temperature, but strongly downregulated under desiccating conditions (Region $\mathrm{B}$ in Figure 2); we, therefore, hypothesized that water availability is a limiting factor. Poikilohydric features have been known to provide lichens with strong tolerance to desiccation [1-3], but the desiccation-rehydration response of Antarctic C. borealis has not been investigated. We therefore first tested the poikilohydric response of $C$. borealis. We collected the thalli of $C$. borealis at the KGL01 site and measured the $\mathrm{Y}(\mathrm{II})$ value during air-drying $\left(50 \% \mathrm{RH}, 16^{\circ} \mathrm{C}\right)$ in the laboratory at King Sejong Station, Barton Peninsula (Figure 1, Figure S4). Although the laboratory conditions were different from those in the field and the results may not be indicative of the situation in the field, we believe 
that this experiment indicates the time required to dry and rehydrate the lichen and whether it is poikilohydric. The relative water content (RWC) of the thalli constantly decreased over $3 \mathrm{~h}$, while the Y(II) value almost persisted until 20\% of the RWC was achieved over $90 \mathrm{~min}$ of air-drying; thereafter, a rapid decline was observed (Figure S4). After $24 \mathrm{~h}$ of air-drying, the fluorescence value of $C$. borealis was no longer detected but it was dramatically recovered up to $90 \%$ after $10 \mathrm{~min}$ of rehydration with distilled water (Figure S4), confirming that $C$. borealis has this poikilohydric feature and a rapid repairing mechanism for desiccation damage $[9,12,57]$. The inactivation and reactivation of photosynthesis depending on the desiccation-rehydration cycle is believed to be a general phenotype of lichens observed in most terrestrial habitats, temperate regions, deserts, and the Arctic and Antarctic regions $[6,8,55,56]$. Next, to understand how $C$. borealis responds to desiccation-rehydration (Regions $B$ and $\mathrm{C}$ in Figure 2), we performed a rapid light curve (RLC) experiment to reproduce the microclimate conditions of the species' natural habitat (Figure 2); two light intensities, $50 \mu \mathrm{mol} / \mathrm{m}^{2} / \mathrm{s}$ (dawn light) and $220 \mu \mathrm{mol} / \mathrm{m}^{2} / \mathrm{s}$ (daytime light) were tested, with mild and severe desiccation conditions of $85 \% \mathrm{RH}$ for slow desiccation (SD) and 5\% RH for rapid desiccation (RD), respectively (Figure 4, Figure S5).
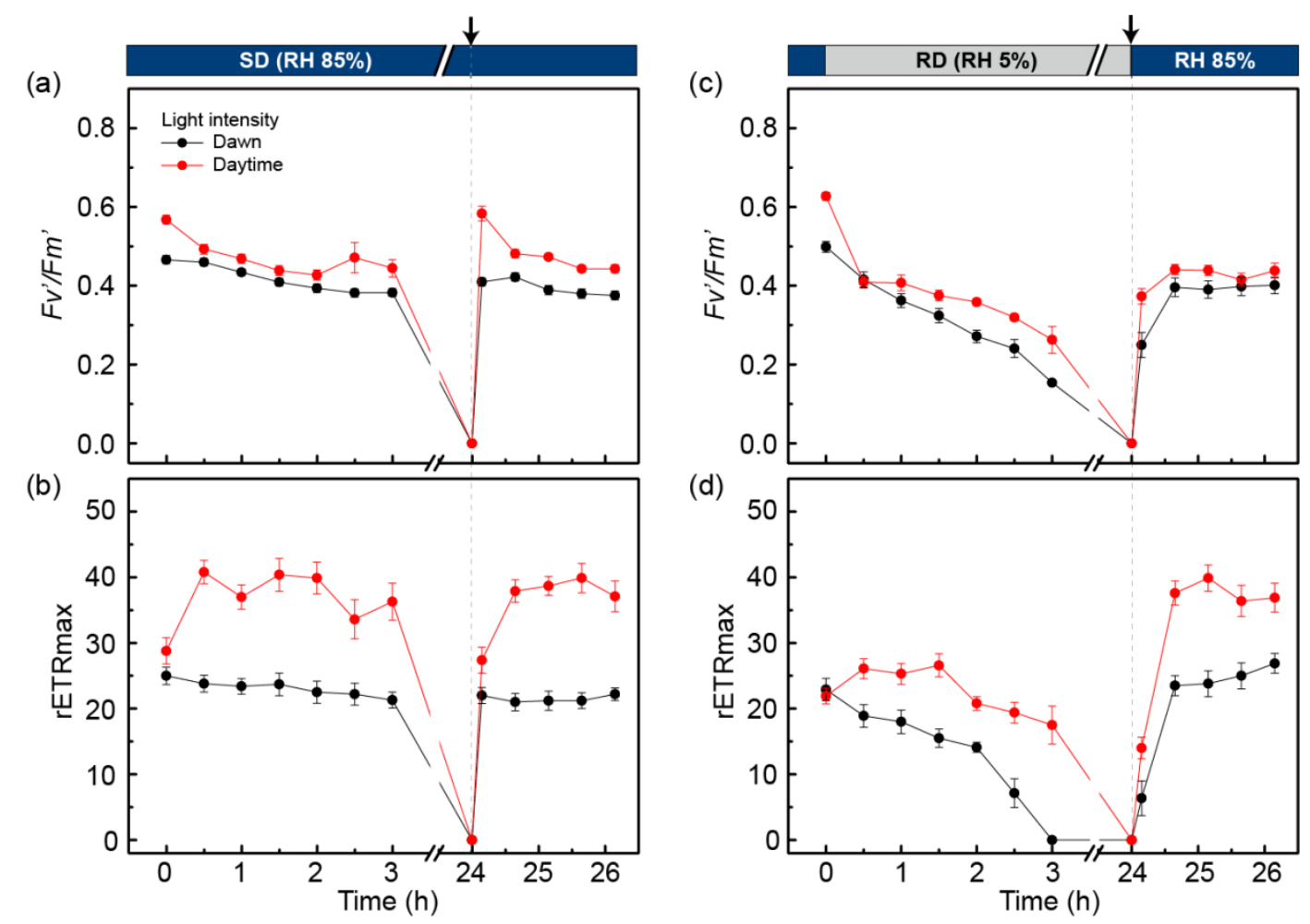

Figure 4. Changes in maximal photosynthetic yield $\left(F v^{\prime} / F m^{\prime}\right)(\mathbf{a}, \mathbf{c})$ and $\operatorname{rETRmax}(\mathbf{b}, \mathbf{d})$ with dawn-light $\left(50 \mu \mathrm{mol} / \mathrm{m}^{2} / \mathrm{s}\right)$ and daytime-light $\left(220 \mu \mathrm{mol} / \mathrm{m}^{2} / \mathrm{s}\right)$ under a desiccation-rehydration cycle in $\mathrm{C}$. borealis. Before desiccation, samples were activated with light $\left(50 \mu \mathrm{mol} / \mathrm{m}^{2} / \mathrm{s}\right)$ for $2 \mathrm{~h}$ under fully hydrated conditions with distilled water. The thalli were treated under slow desiccation (SD, 85\% RH) (a,b) and rapid desiccation ( $\mathrm{RD}, 5 \% \mathrm{RH})(\mathrm{c}, \mathrm{d})$ for $24 \mathrm{~h}$ (until indicated by the dashed line), and then rehydrated with a water spray of distilled water (black arrow). After the removal of excess water, both samples were kept under SD conditions for an additional $2 \mathrm{~h}$. The ten biological replicates were used for each treatment $(n=10)$. Experiments were repeated at least two or three times using the same thalli after re-stabilizing at $50 \mu \mathrm{mol} / \mathrm{m}^{2} / \mathrm{s}$ light with an 18:6 light:dark cycle at $8{ }^{\circ} \mathrm{C}$ with hydration for a week. Results are the means with \pm standard deviation shown by vertical bars.

Under SD conditions for $3 \mathrm{~h}$, the maximal photosynthetic yield $\left(F v^{\prime} / F m^{\prime}\right)$ and rETRmax of the dawn-light samples were slightly decreased to approximately $90 \%$ of their initial state (Figure $4 a, b$ ). After $24 \mathrm{~h}$ of treatment under SD conditions, fluorescence was not detected because the RWC of the samples was less than $10 \%$. After 10 min of rehydration with distilled water, the $F v^{\prime} / F m^{\prime}$ and rETRmax 
were completely recovered to their initial state. For the daytime-light samples, the $F v^{\prime} / F m^{\prime}$ value gradually decreased to $\sim 80 \%$ of the initial value during $3 \mathrm{~h}$ of treatment, while the rETRmax increased to 1.5 -fold the initial value after $30 \mathrm{~min}$ of treatment. The values were then slightly decreased to $\sim 90 \%$ of their maximums. After $10 \mathrm{~min}$ of rehydration, the $F v^{\prime} / F m^{\prime}$ and rETRmax of the daytime-light samples completely recovered to their initial state. These results indicate that the photosystem of $C$. borealis has SD resistance and a rapid repairing mechanism after rehydration. In addition, the increase in light intensity could help to improve the PSII efficiency and electron transfer rate in the photosystem.

The RD conditions caused some oxidative damage in the photosystem of $C$. borealis compared to the samples treated with SD (Figure 4c,d). For the dawn-light samples treated for $3 \mathrm{~h}$ with RD, the $F v^{\prime} / F m^{\prime}$ value declined to $\sim 20 \%$ of its initial state, and the rETRmax disappeared. After rehydration of the 24 h-dehydrated samples, $F v^{\prime} / F m^{\prime}$ was restored to $\sim 80 \%$ of its initial value, and rETRmax completely recovered within $1 \mathrm{~h}$ of rehydration. For the daytime-light samples under RD conditions, $F v^{\prime} / F m^{\prime}$ was reduced to $\sim 50 \%$ of its initial state after $3 \mathrm{~h}$ of treatment. In contrast, rETRmax was slightly increased ( 1.1-fold) after a 30-min treatment but then decreased to $\sim 80 \%$ of its initial state by $3 \mathrm{~h}$. After rehydration of the $24 \mathrm{~h}$-dehydrated daytime-light samples, the $F v^{\prime} / F m^{\prime}$ value reached $\sim 80 \%$ of its initial value, similar to the rehydration response of the dawn-light samples. Such responses could imply that the increase in light intensity from dawn to daytime plays a positive role in enhancing PSII efficiency and electron transfer to PSI, just like the SD treatment.

Interestingly, the rETRmax of the rehydration response was quite different from that of the RD-treated samples, which increased to twice the initial state, a value that is similar to that of the SD-treated samples (Figure 4d). From this result, we inferred that the RD conditions in this experiment could damage the oxygen-evolving center (OEC) of PSII but not the electron transfer process through plastoquinone (PQ) and PSI. In fact, the OEC component is easily exposed to ROS because it plays an important role in generating the electron gradient by charge separation from water molecules to electrons and oxygen molecules using light energy [42,48]. Furthermore, desiccation stress can severely affect the OEC component of PSII owing to the depletion of water molecules, and the photo-excited pigments easily produce ROS even under low-light conditions [58]. By sequential electron flow, oxidative pressure can damage PQ, which is the first molecule to be oxidized by P680+, and the PSI side as well [48]. Excessive or uncontrolled ROS levels are harmful to essential molecules, including nucleic acids, proteins, and lipids [42]. In C. borealis, however, the ETR reaction was completely rescued by rehydration, but the photosynthetic efficiency of PSII was not; therefore, we assume that the applied desiccation conditions damaged PSII, but not the PQ or PSI side.

\subsection{PSII Photochemistry Changes in C. borealis during the Dehydration Response}

The photosystem of $C$. borealis showed rapid repair via rehydration after SD and RD treatments. In particular, increased light intensity (50 to $220 \mu \mathrm{mol} / \mathrm{m}^{2} / \mathrm{s}$ ) enhanced the recovery of PSII efficiency $\left(F v^{\prime} / F m^{\prime}\right)$ and the electron transfer rate (Figure 4), and we, therefore, hypothesized that PSII protective mechanisms are induced by the changes in light intensity from dawn to daytime. From the RLC experiment, we could deduce how photosystem performance changed under saturated light conditions [59]. During SD, RD, and rehydration responses, the absorbed light energy can be used in a different manner depending on PSII status. Absorbed light energy can be competitively used for photochemistry at the reaction center of PSII, heat dissipation in NPQ, and re-emission of fluorescence. The efficiency of light energy usage can be calculated by the photochemical reaction, Y(II), the regulated non-photochemical reaction as heat dissipation, $\mathrm{Y}(\mathrm{NPQ})$, and the non-regulated non-photochemical reaction, $\mathrm{Y}(\mathrm{NO})$ : $\mathrm{Y}(\mathrm{II})+\mathrm{Y}(\mathrm{NPQ})+\mathrm{Y}(\mathrm{NO})=1$ [60]. Thus, the PSII photochemistry changes in $C$. borealis under the given conditions indicate the photosystem response to a desiccation-rehydration cycle during the daytime (Figure 5). 
(a)

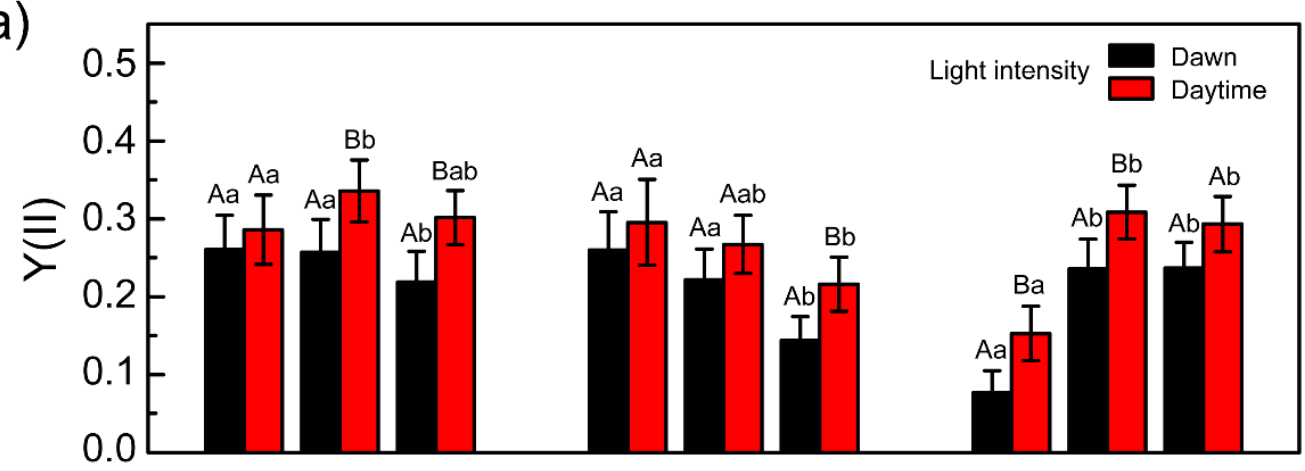

(b)

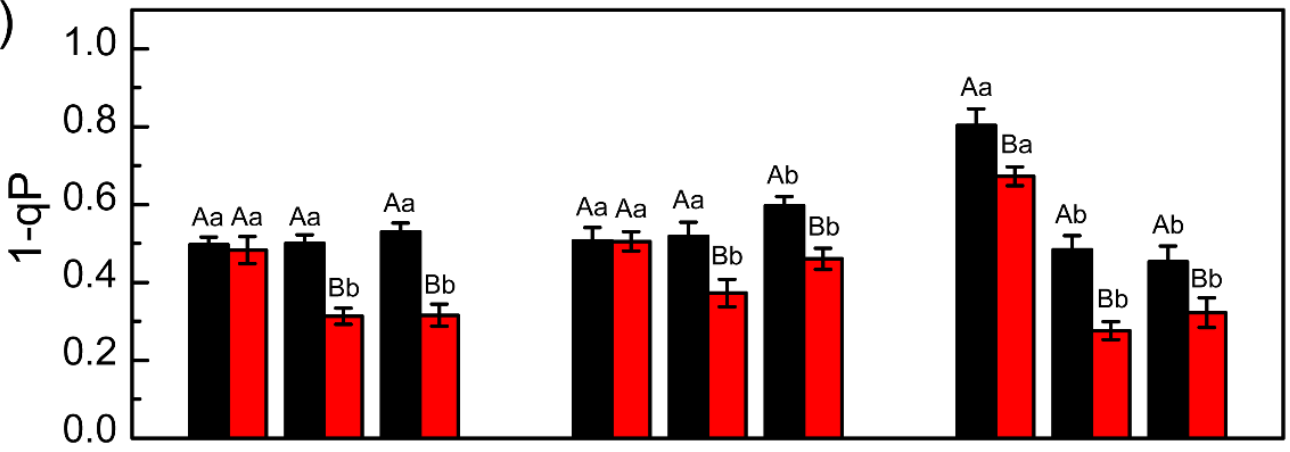

(c)

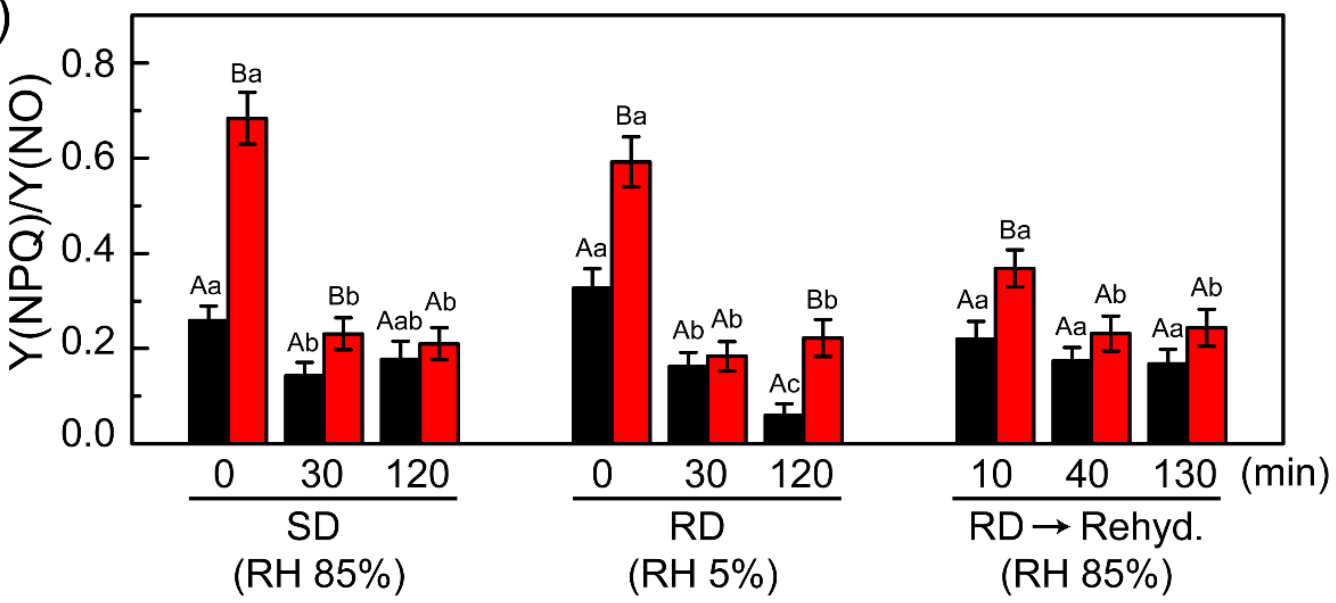

Figure 5. PSII photochemistry changes during RLC experiments under the given conditions. (a) Effective photosynthetic yield $\mathrm{Y}(\mathrm{II})$, (b) 1-qP value, and (c) $\mathrm{Y}(\mathrm{NPQ}) / \mathrm{Y}(\mathrm{NO})$ ratio. Each value indicates the average score \pm standard deviation, calculated from the data in Figure S6. The average was calculated by two-way ANOVA, and its significant differences among the data were analyzed based on the Tukey's HSD test (at $p<0.05$ ) which was displayed with different letters; upper case letters indicate the effects of light intensity at the same time of desiccation (or rehydration) treatment, and lower case letters indicate the effects of desiccation (or rehydration) treatment at the same light condition. The ten biological replicates were used for each treatment $(n=10)$. Experiments were repeated at least two or three times using the same thalli after re-stabilizing at $50 \mu \mathrm{mol} / \mathrm{m}^{2} / \mathrm{s}$ light with an $18: 6$ light:dark cycle at $8{ }^{\circ} \mathrm{C}$ with hydration for a week. Black and red bars represent dawn light $\left(50 \mu \mathrm{mol} / \mathrm{m}^{2} / \mathrm{s}\right)$ and daylight $\left(220 \mu \mathrm{mol} / \mathrm{m}^{2} / \mathrm{s}\right)$, respectively. Y(NPQ), the efficiency of the regulated non-photochemical quenching reaction; $\mathrm{Y}(\mathrm{NO})$, the efficiency of the nonregulated non-photochemical quenching reaction; $\mathrm{SD}$, slow desiccation; RD, rapid desiccation; RD $\rightarrow$ Rehyd., rehydration after $24 \mathrm{~h}$ of $\mathrm{RD}$ treatment.

During daylight treatment, the Y(II) values were slightly higher than those of the dawn-light samples under $\mathrm{SD}, \mathrm{RD}$, and rehydration after $\mathrm{RD}$ exposure; however, the change in their patterns was similar (Figure 5a). The 1-qP value, which represents pressure of the PSII reaction center [61,62], was 
the same initially under SD and RD conditions, but this value was reduced in the daylight samples compared with that in the dawn light samples during treatment under both conditions (Figure 5b). This phenomenon could indicate that the PSII reaction center of the daylight samples was protected against induced pressure during treatment, after initiation. The rehydration response also showed that the dawn-light samples had slightly higher pressure than the daylight samples. This is consistent with the recovery rates of $F v^{\prime} / F m^{\prime}$ and rETR in the dawn-light samples, which were delayed relative to the values of the daylight samples (Figure 4).

Therefore, we suggest that the photosystems of $C$. borealis possess some protective mechanism(s) that are rapidly induced by daylight exposure (within $30 \mathrm{~min}$ ), and these mechanisms can function to reduce pressure at the PSII reaction center. Consequently, these protective mechanisms likely associate with enhancement of PSII efficiency in the daylight samples, even under SD and RD conditions (Figures 4 and 5). To clarify this possibility, the process had to be examined in more detail.

One possibility for the daylight induced-photoprotective mechanism is an NPQ process in $C$. borealis. The $\mathrm{Y}(\mathrm{NPQ})$ and $\mathrm{Y}(\mathrm{NO})$ values represent the NPQ process, but the former is a regulated reaction that usually indicates heat dissipation by the xanthophyll cycle and some carotenoids, while the latter is a nonregulated reaction including the re-emission of light and photodamage [60]. The Y(NPQ)/Y(NO) ratio shows how excess light energy is used at the PSII reaction center. The $Y(N P Q) / Y(N O)$ value of the daylight samples was 2-fold higher than that of the dawn-light samples at the start of SD and RD treatments (Figure 5c). Such a finding indicates that the NPQ process was further induced by daylight exposure, but after treatment initiation, it was stabilized under the SD and RD conditions. In general, the NPQ process has at least three components: $\mathrm{pH}$-regulated energy dissipation in the antenna system of PSII, a state transition between PSII and PSI, and a photoinhibitory quenching process (qE, $\mathrm{qT}$, and $\mathrm{qI}$, respectively) [63-66]. These quenching processes have different reaction time scales, and qE usually has a fast phase of relaxation $[67,68]$. Our results could not determine which NPQ component plays a major role in the photoinhibition mechanism, but we speculate that $\mathrm{qE}$ could contribute to a rapid reduction in PSII pressure in C. borealis. This qE quenching process is activated by the enzymatic conversion of violaxanthin to zeaxanthin, called the xanthophyll cycle. The xanthophyll cycle is generally associated with desiccation tolerance in lichens [18-22]. For example, in Lobaria pulmonaria, the light-dependent xanthophyll cycle can enhance desiccation tolerance [69] and the generation of light-independent zeaxanthin plays an antioxidant role in stabilizing the membrane and downregulating photosynthetic efficiency [70].

This laboratory experiment could provide clues to understand the continuous and rhythmic photosynthetic performance of $C$. borealis in Antarctic environments. These changes in PSII photochemistry demonstrate that rapid NPQ induction by increased light intensity can enhance desiccation tolerance, and such phenomena are presumably associated with microclimate changes in the Antarctic region. As photosynthetic organisms in this area have a short growing season (December to February), they must create a balance between growth proliferation and a reduction in damage from environmental stressors. In the natural habitat, fluctuations in light, temperature, and humidity generate high pressure on PSII, resulting in excess ROS formation. Moreover, a lack of water molecules with sunlight exposure may overexcite the reaction center of PSII, regardless of low lighting [71], thereby resulting in a reduction in photosynthetic efficiency. To date, the photosynthetic performance of $C$. borealis has been shown to be highly susceptible to changes in environmental conditions, and we expect that such a shade-adapted lichen species has additional tightly regulated photoinhibition mechanisms owing to its complicated microclimate changes.

\subsection{Major Photobiont of C. borealis Is Asterochloris Irregularis}

Lichens are composed mainly of mycobionts (fungi) and photobionts (algae and/or cyanobacteria), but it was recently discovered that yeast can be involved as a third partner [72]. Thus, the interaction of symbiotic organisms within lichens continues to be a fascinating topic. To identify the photobiont of Antarctic C. borealis, we carried out amplicon sequencing of two field samples using the algal-specific 
ITS region (Table 2, Table S3). The total sequencing reads were over $390 \mathrm{Mb}$ in length, and the number of reads was 1,302,402 and 1,327,794, respectively. Approximately $70 \%$ of the total sequencing reads were successfully connected to 453,505 and 480,246 read pairs, and after removing low-quality sequences, the final clustered reads were $53.1 \mathrm{Mb}$ and $49.5 \mathrm{Mb}$ in length (Table S3). For multiple alignments and BLAST search analyses, 98.9-99\% of the reads were matched to Asterochloris irregularis (NCBI accession AM906000) with over 98\% identity. Although the remaining reads-comprising Coccomyxa antarctica, Trebouxia irregularis, Trebouxia jamesii, and Trebouxia impressa from Trebouxiophyceae, and Coenochloris signiensis and uncultured Chlorophyta taxa from Chlorophyceae-constituted less than $0.1 \%$, these accessory algae are worth exploring further (Table 2).

Table 2. Photobiont species list of two Antarctic Cladonia borealis samples analyzed by amplicon sequencing of the ITS region.

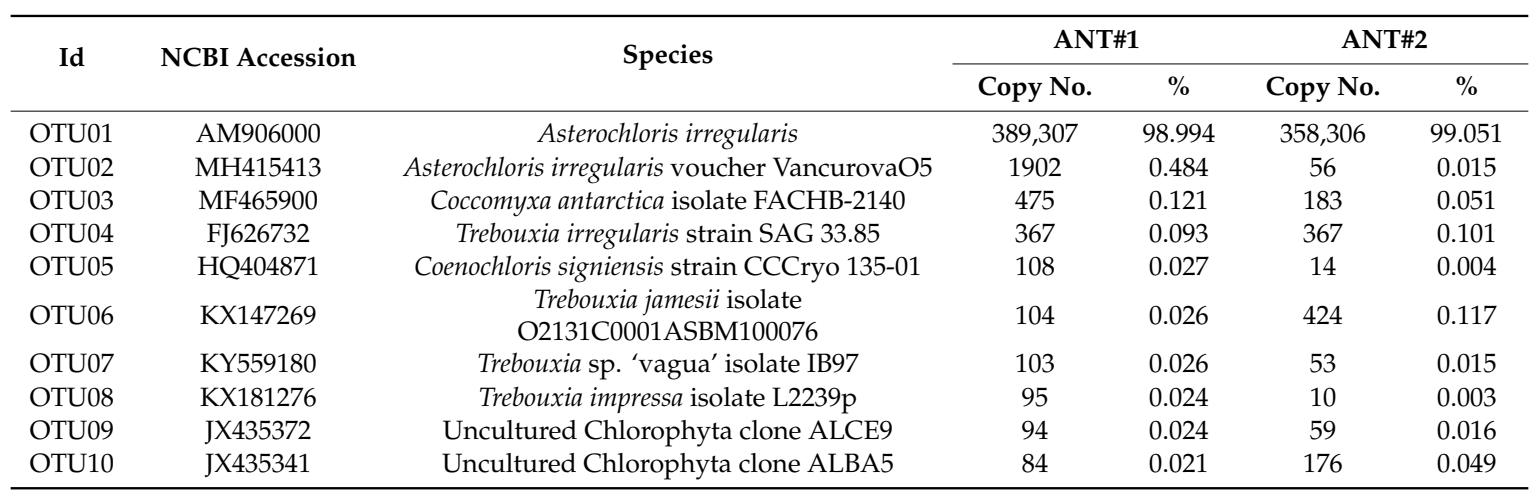

The genus Asterochloris is composed of a photobiont of more than 20 lichen genera, predominantly Cladonia, Lepraria, and Stereocaulon, in diverse habitats [73-82]. Recently, A. irregularis was reported to be a photobiont of Cladonia arbuscula, Stereocaulon pileatum, Stereocaulon subcoralloides, and Stereocaulon botryosum in Central and Eastern Europe, and was suggested to be a discriminated species based on its molecular phylogeny of combined ITS and actin 1 sequences, its chloroplast morphology, and its morphological features during cell division [80]. In this study, we report that A. irregularis is the major photobiont of Antarctic C. borealis, and its photosynthetic performance is downregulated during daytime in its natural habitat. In addition, the NPQ reactions of $C$. borealis were induced by daytime light intensity and desiccating conditions. We surmise that such photosynthetic performance is derived from the photobionts, but how such physiological responses are regulated between isolated photobionts and fungal partners should be carefully examined. In a study of C. vulcani, for example, the photoprotective response to desiccation and irradiation stress was further enhanced in the lichen form compared to either the isolated mycobiont or phycobiont. During 9 weeks of desiccation, the lichen form maintained photosynthetic pigments, including chlorophyll and xanthophyll, together with the antioxidant $\alpha$-tocopherol, which completely recused them after rehydration. However, the isolated alga failed to do so. Such phenotypes highlight that biochemical interactions between the fungal and algal partners are essential to resist oxidative and high light stress in nature [21]. Therefore, comparison of the physiological responses between the lichen C. borealis and its photobionts is necessary to elucidate the regulatory pathways of resistance to desiccation and light stress.

\section{Materials and Methods}

\subsection{Microclimate and Chlorophyll Fluorescence Measurement in the Field}

Field observation was carried out from 23-30 January 2019 at the KGL01 site (KGL01: 62¹4’24” S, $58^{\circ} 44^{\prime} 36^{\prime \prime}$ W), Barton Peninsula, King George Island. Three thalli of each C. borealis and Usnea sp. were selected for chlorophyll fluorescence measurements. Any moss was carefully removed to minimize fluorescence interference. Chlorophyll fluorescence monitoring was performed using MONI-PAM 
(MONITORING-PAM Multi-Channel Chlorophyll Fluorometer, Walz, Effeltrich, Germany), which was composed of a data acquisition system (MONI-DA) and six emitter-detector units (MONI-head/485) connected to HEX-PAM. The operation method and its application were derived from those published by Porcar-Castella et al. [83]. A blue LED (emission maximum: $455 \mathrm{~nm} \pm 9 \mathrm{~nm}$ ) was used as the light source for actinic light, saturating pulse, and measuring light. In this study, the light intensity for measuring light was $0.9 \mu \mathrm{mol} / \mathrm{m}^{2} / \mathrm{s}$ and the saturating pulse was approximately $2500 \mu \mathrm{mol} / \mathrm{m}^{2} / \mathrm{s}$ with a duration of up to $2 \mathrm{~s}$. To reduce the actinic light effect on samples, the lights were turned off between measuring points and automatically turned on a few seconds before the saturating pulse analysis. Fluorescence $\left(F\right.$ and $\left.F m^{\prime}\right)$ was detected before and after a saturating pulse every $20 \mathrm{~min}$. At the same time, the PPFD and temperature were recorded.

There were six MONI-heads fixed to the lichen samples, three for the Usnea sp. and three for C. borealis, at a $120^{\circ}$ angle from the horizontal axis, but two failed to retrieve data. Volumetric soil moisture was measured at a depth of $10 \mathrm{~cm}$ using a Soil Moisture Smart Sensor (\#EC-5, Decagon Devices, Pullman, WA, USA) and recorded by a HOBO Micro Station Data Logger (\#H21-002, Onset, Bourne, MA, USA) every $10 \mathrm{~min}$. Rainfall records, assessed every $10 \mathrm{~min}$, were acquired from the AWS managed by the Climate Research Group at King Sejong Station.

\subsection{Genomic DNA Extraction and Lichen Identification}

C. borealis samples, with a similar size and weight (without podetia), were collected from the KGL01 site and transferred to the laboratory at King Sejong Station. Two thalli were used for total genomic DNA extraction. The samples were washed twice with 70\% ethanol and $0.1 \%$ Tween 20 and rinsed with distilled water (DW). The dried sample was ground with liquid nitrogen, and total genomic DNA was extracted by the cetyltrimethylammonium bromide (CTAB) method [84]. Total genomic DNA was used for both lichen identification and amplicon sequencing of the photobiont. For lichen identification, the ITS region was amplified from the prepared total genomic DNA (\#1 and \#2) using fungal-specific ITS1 and ITS4 primers [85]. The purified PCR product was used for sequencing analysis (Bionics, Seoul, Korea) and the sequencing results were used for BLAST searches in NCBI.

\subsection{Desiccation and Rehydration Treatment}

The air-drying experiment was performed using field samples in a laboratory at King Sejong Station, Barton Peninsula. DW with an ion conductivity of $10 \mu \mathrm{S} / \mathrm{cm}$ (pH 7.8) was used for rehydration. A preliminary experiment confirmed that the water content of $C$. borealis thalli reaches full rehydration in $10 \mathrm{~min}$, when its total weight no longer increases (data not shown). Based on this result, we used the following method to rehydrate the thalli: spray with distilled water for $10 \mathrm{~min}$ and then remove excess water from the thalli using Kimwipes (Kimberly-Clark Professional, Roswell, GA, USA). Before air-drying, 10 individual samples were fully rehydrated as described above. The air-drying experiment was performed under the following laboratory conditions: air humidity was $50 \%$, temperature was $16{ }^{\circ} \mathrm{C}$, and light intensity was $50 \mu \mathrm{mol} / \mathrm{m}^{2} / \mathrm{s}$. Thallus weight and $F v^{\prime} / \mathrm{Fm}^{\prime}$ were measured every 10 min using the MINI-PAM-II fluorometer (Walz) until there was no change in weight, which required approximately $3 \mathrm{~h}$. After an additional $21 \mathrm{~h}$ of air-drying, fluorescence was no longer detected. However, after $10 \mathrm{~min}$ of rehydration with the water spray, fluorescence was detected. This rehydrated state was maintained for $3 \mathrm{~h}$ and the fluorescence was measured. The RWC of the sample during dehydration was measured using an analytical balance (\#PG503-S, METTER TOLEDO, Greifensee, Switzerland) to a precision of $0.1 \mathrm{mg}$. The RWC was calculated as described by Sun [86].

The RLC experiment under different light intensities and desiccation conditions was carried out at the laboratory of the Korea Polar Research Institute (Incheon, Korea) using IMAGING-PAM (Walz). The samples were stabilized at $50 \mu \mathrm{mol} / \mathrm{m}^{2} / \mathrm{s} \mathrm{light} \mathrm{with} \mathrm{an} 18: 6$ light:dark cycle at $8{ }^{\circ} \mathrm{C}$ with hydration every three days in a growth chamber. To reproduce the microclimate conditions of the species' natural habitat (Figure 2), we established two light intensities- 50 and $220 \mu \mathrm{mol} / \mathrm{m}^{2} / \mathrm{s}-$ based on the average light intensity at dawn (04:00-06:00) and daytime (06:00-22:00), respectively. These 
average light intensities were calculated from $>50 \%$ of the $Y$ (II) value to exclude conditions that damage photosynthetic activity. In addition, the temperature was fixed at $8{ }^{\circ} \mathrm{C}$ to minimize low-temperature stress conditions. We chose mild and severe desiccation conditions of $85 \% \mathrm{RH}$ for SD and $5 \% \mathrm{RH}$ for $R D$, respectively. SD and RD were prepared in a humid box $(20 \mathrm{~cm} \times 15 \mathrm{~cm} \times 20 \mathrm{~cm})$ with $20 \mathrm{~mL}$ of DW ( $\mathrm{RH} \sim 85 \%$ ) or silica gel $(\mathrm{RH}<5 \%)$, respectively. The samples were placed on a mesh plate $10 \mathrm{~cm}$ from the bottom for the given desiccation treatment. Ten individual samples were used for each SD and RD treatment after $2 \mathrm{~h}$ of light activation at $50 \mu \mathrm{mol} / \mathrm{m}^{2} / \mathrm{s}$. Rehydration after desiccation treatment for 24 $\mathrm{h}$ was conducted with a water spray, and excess water was removed before the rehydrated samples were transferred to the SD container (RH 85\%). Desiccation and rehydration treatments for the RLC experiment were performed using ten biological replicates for each condition. A total of forty thalli was used for four conditions (two light intensities $x$ two desiccation conditions). Experiments for SD and RD treatments were repeated two and three times, respectively. After desiccation-rehydration treatment, the samples were re-stabilized at $50 \mu \mathrm{mol} / \mathrm{m}^{2} / \mathrm{s}$ light with an $18: 6$ light:dark cycle at $8{ }^{\circ} \mathrm{C}$ with hydration for a week.

\subsection{Chlorophyll Fluorescence Measurement in the Laboratory}

For the RLC experiment, chlorophyll fluorescence was measured using IMAGING-PAM (Walz,) during desiccation-rehydration treatment. After $6 \mathrm{~h}$ in the dark, minimum chlorophyll fluorescence $(F o)$ and maximum chlorophyll fluorescence $(\mathrm{Fm})$ elicited by a strong saturation pulse were measured and then used to calculate the maximal photochemical quantum yield $(F v / F m): F v / F m=(F m-F o) / F m[41]$. The average $F v / F m$ value of $C$. borealis samples stored in the dark was $\sim 0.62( \pm 0.03)$. Desiccation and rehydration treatment was conducted under the same light cycle (18:6 light:dark), which began after $2 \mathrm{~h}$ of light activation. The effective PSII quantum yield (YII) or $F v^{\prime} / F m^{\prime}=\left(F m^{\prime}-F\right) / F m^{\prime}$ was calculated from the light-activated samples [41]. The $\mathrm{Fm}^{\prime}$ value represents the maximum fluorescence yield in a light-adapted sample, while the $F^{\prime}$ value represents the level of fluorescence shortly before the application of the saturating pulse [41]. The RLC reveals the saturation features of electron transport and the overall photosynthetic performance in plants [58]. The RLC experiment for the desiccation-rehydration cycle was performed under $50 \mu \mathrm{mol} / \mathrm{m}^{2} / \mathrm{s}$ (dawn light) and $220 \mu \mathrm{mol} / \mathrm{m}^{2} / \mathrm{s}$ (daylight) conditions every $30 \mathrm{~min}$. The coefficient of photochemical fluorescence quenching, $\mathrm{qP}$, was calculated as $\left(F m^{\prime}-F\right) /\left(F m^{\prime}-F o\right)[61,62]$. The quantum yield of non-light induced non-photochemical fluorescence quenching, $\mathrm{Y}(\mathrm{NO})$ was calculated as $1 /[\mathrm{NPQ}+1+\mathrm{qL} \times(F m / F o-1)]$ [60]. The quantum yield of light-induced NPQ was calculated as $Y(N P Q)=1-Y(I I)-Y(N O)$ [60]. The curve fitting method of Ralph and Gademann was utilized [58].

\subsection{High-Throughput Amplicon Sequencing for Photobiont Diversity}

Total genomic DNA from two $C$. borealis samples was used to amplify the algal ITS2 region with 5.8SF (5'-CGG ATA TCT TGG CTC TCG CA-3') and LSU0012_R (5'-AGT TCA GCG GGT CTT G-3') primers [79] in conjunction with adapter sequences of the Illumina Miseq platform. The first PCR was conducted with a $15-\mu \mathrm{L}$ reaction volume containing $3 \mu \mathrm{L}$ of $5 \times$ Phusion HF Buffer, $1.5 \mu \mathrm{L}$ of 2 mM dNTPs, $1.5 \mu \mathrm{L}$ of primer mix $(10 \mu \mathrm{M}), 1.5 \mu \mathrm{L}$ of $3 \mathrm{M}$ betaine, $1 \mu \mathrm{L}$ of template DNA, $0.1 \mu \mathrm{L}$ of Phusion DNA polymerase, and $6.4 \mu \mathrm{L}$ DW. The PCR cycle conditions included initial denaturation at $98^{\circ} \mathrm{C}$ for $30 \mathrm{~s}$, followed by 20 cycles of denaturation at $98^{\circ} \mathrm{C}$ for $30 \mathrm{~s}$, annealing at $60^{\circ} \mathrm{C}$ for $1 \mathrm{~min}$, and extension at $72{ }^{\circ} \mathrm{C}$ for $15 \mathrm{~s}$, with a final extension at $72{ }^{\circ} \mathrm{C}$ for $5 \mathrm{~min}$. The PCR product was confirmed on a $1 \%$ agarose gel stained with GelRed and the remaining primers and dNTPs were removed using ExoSAP-IT PCR product cleanup reagent (\#78200, ThermoScientific, Seoul, Korea). The purified PCR product was used as a template for secondary PCR for conjugation with the index sequences (i5 and i7). The secondary PCR was performed in a $20-\mu \mathrm{L}$ reaction volume containing $4 \mu \mathrm{L}$ of $5 \times$ Phusion HF Buffer, $2 \mu \mathrm{L}$ of $2 \mathrm{mM}$ dNTPs, $2 \mu \mathrm{L}$ of $3 \mathrm{M}$ betaine, $2 \mu \mathrm{L}$ of primer mix $(5 \mu \mathrm{M}), 3 \mu \mathrm{L}$ of purified PCR product, $0.2 \mu \mathrm{L}$ of Phusion DNA polymerase, and $6.8 \mu \mathrm{L}$ DW. The PCR cycle conditions included initial denaturation at $98^{\circ} \mathrm{C}$ for $30 \mathrm{~s}$, followed by 25 cycles of denaturation at $98^{\circ} \mathrm{C}$ for $30 \mathrm{~s}$, annealing 
at $60{ }^{\circ} \mathrm{C}$ for $15 \mathrm{~s}$, and extension at $72{ }^{\circ} \mathrm{C}$ for $15 \mathrm{~s}$, with a final extension at $72{ }^{\circ} \mathrm{C}$ for $5 \mathrm{~min}$. The PCR product was quantified and the clean-up reaction was repeated.

Paired-end (PE) reads averaging $301 \mathrm{bp}$ were produced by the Illumina MiSeq platform and merged into connected sequences of 379-383 bp by joining both ends using clc_assembly_cell version 4.3 (https://www.qiagenbioinformatics.com/products/clc-assembly-cell/). Low-quality sequences were removed from the connected sequences using Trimmomatic version 0.38 (http://www.usadellab. org/cms/?page=trimmomatic) with the following parameters: minimum quality, 20 and minimum length, 50. The high-quality connected sequences were clustered based on the criterion of $100 \%$ homology using CD-HIT version 4.7 (http://weizhongli-lab.org/cd-hit/). Thereafter, representative sequences and their copy number information were obtained. Representative sequences were used as nucleotide queries for similarity searches. Similarity searches for nucleotide and peptide queries were performed against the NCBI non-redundant nucleotide database using BLAST version 2.7.1+ (https://ncbiinsights.ncbi.nlm.nih.gov/2017/10/27/blast-2-7-1-now-available/) with a cutoff $e$-value of $1 \times 10^{-4}$. Hit subject sequences with $>98 \%$ identity were further selected from the similarity results; their NCBI taxonomy information was extracted and used for taxonomical classification of the query sequences.

\subsection{Statistical Analysis}

For the data shown in Figure 3, the linear fitting analysis between Y(II) and the three microclimate parameters was performed using Origin 8.5 (OriginLab Corp., Northampton, MA, USA). The slope, standard error (SE), and $\mathrm{R}^{2}$ values were calculated from this linear fitting analysis. In Figure 5 , the mean value was calculated by two-way ANOVA, and mean comparison among the data was analyzed based on the Tukey's honestly significant difference (HSD) test. Significant differences among treatments were denoted with different letters at $p<0.05$ level. This statistical analysis was performed using SigmaPlot 11 software (Systat Software Inc., San Jose, CA, USA).

Supplementary Materials: The following are available online at http:/www.mdpi.com/2223-7747/9/1/85/s1, Figure S1: Monthly changes in microclimate factors at the study site, KGL01, in Barton Peninsula, Antarctica, Figure S2: Diurnal dynamics of (a) PPFD $\left(\mu \mathrm{mol} / \mathrm{m}^{2} / \mathrm{s}\right),(\mathrm{b})$ temperature $\left({ }^{\circ} \mathrm{C}\right),(\mathrm{c})$ volumetric soil moisture $(\%)$, (d) the $Y($ II) of $C$. borealis and (e) the Y(II) of Usnea sp, Figure S3: Plots of Y(II) with three microclimate factors recorded during all period of field observation, Figure S4: Air-drying of field C. borealis samples with changes of (a) RWC (\%), (b) the Y(II) value, and (c) the relative recovery rate of Y(II) after rehydration, Figure S5: The rapid light curves of $C$. borealis by desiccation and rehydration treatment under different light intensity, dawn-light $\left(50 \mu \mathrm{mol} / \mathrm{m}^{2} / \mathrm{s}\right)$ and daytime-light $\left(220 \mu \mathrm{mol} / \mathrm{m}^{2} / \mathrm{s}\right)$, Figure S6: Changes of Y(II), Y(NPQ) and 1-qP of C. borealis during rapid light curve experiment under the slow desiccation (SD), rapid desiccation (RD) and rehydration after $24 \mathrm{hr}$-RD treatment (RD $\rightarrow$ Rehyd.) with different light intensity, dawn-light $\left(50 \mu \mathrm{mol} / \mathrm{m}^{2} / \mathrm{s}\right)$ and daytime-light $\left(220 \mu \mathrm{mol} / \mathrm{m}^{2} / \mathrm{s}\right)$, Table S1: The mean, min and max values of Y(II) of C. borealis and the microclimates, Table S2: Linear regression of $Y($ II) with three microclimate factors during all period of field observation, Table S3: Results of high-throughput amplicon sequencing output amplifying the algal specific ITS region from two samples of $C$. borealis.

Author Contributions: Methodology, S.M.C.; validation, S.M.C.; formal analysis, S.M.C.; data curation, S.M.C. and J.L.; writing-original draft preparation, S.M.C. and J.L.; writing-review and editing, S.M.C., J.L., H.L. and S.G.H. All authors have read and agreed to the published version of the manuscript.

Funding: This research was funded by the Korea Polar Research Institute (PE20170).

Acknowledgments: We would like to extend special thanks to Mi Young Byun, Junhwa Chi, and Seung Chul Shin for helping with the field experiments during the expedition season and to Mincheol Kim for his advice and discussion on statistical analysis.

Conflicts of Interest: The authors declare no conflict of interest. 


\section{Abbreviations}

$\mathrm{Y}(\mathrm{II}) \quad$ Quantum efficiency of photosystem II

$\mathrm{Y}(\mathrm{NO}) \quad$ Quantum yield of nonregulated and non-photochemical energy dissipation at photosystem II

Y(NPQ) Quantum yield of non-photochemical quenching at photosystem II

NPQ non-photochemical quenching

ETR Electron transfer rate

PSII Photosystem II

PSI Photosystem I

OEC Oxygen evolving center

PQ Plastoquinone

ROS Reactive oxygen species

PPFD Photosynthetic photon flux density

$\mathrm{RH} \quad$ Relative humidity

RWC Relative water content

RD Rapid desiccation

SD Slow desiccation

RLC Rapid light curve

AWS Automatic weather station

\section{References}

1. Bewley, J.D. Physiological Aspects of Desiccation Tolerance. Annu. Rev. Plant Physiol. 1979, 30, $195-238$. [CrossRef]

2. Kranner, I. Glutathione status correlates with different degrees of desiccation tolerance in three lichens. New Phytol. 2002, 154, 451-460. [CrossRef]

3. Rundel, P.W. Water relations. In Handbook of Lichenology; CRC Press, Inc.: Boca Raton, FL, USA, 1988; Volume 2, pp. 17-36.

4. Green, T.A.; Schroeter, B.; Sancho, L.G. Plant life in Antarctica. In Functional Plant Ecology; CRC Press, Inc.: Boca Raton, FL, USA, 2007; pp. 408-453.

5. Rudolph, E.D. Lichen ecology and microclimate studies at Cape Hallett, Antarctica. In Biometeorogy, Proceedings of the Third International Biometeorological Congress; Pergamon Press: Oxford, UK, 1966; Volume 2, pp. 900-910.

6. Kappen, L. Ecophysiological relationships in different climatic regions. In Handbook of Lichenology; CRC Press, Inc.: Boca Raton, FL, USA, 1988; Volume 2, pp. 37-100.

7. Lange, O.L. Ecophysiology of photosynthesis: Performance of poikilohydric lichens and homoiohydric Mediterranean sclerophylls. J. Ecol. 1988, 76, 915-937. [CrossRef]

8. Nash, T.H., III; Moser, T.J.; Link, S.O. Nonrandom variation of gas exchange within arctic lichens. Can. J. Bot. 1980, 58, 1181-1186. [CrossRef]

9. Oliver, M.J.; Derek Bewley, J. Desiccation-tolerance of plant tissues: A mechanistic overview. Hortic. Rev. 1996, 18, 171-213.

10. Alpert, P.; Oliver, M.J. Drying without dying. In Desiccation and Survival in Plants: Drying without Dying; CABI Publishing: Wallingford, CT, USA, 2002; pp. 3-43.

11. Proctor, M.C.; Pence, V.C. Vegetative tissues: Bryophytes, vascular resurrection plants and vegetative propagules. In Desiccation and Plant Survival; CABI Publishing: Wallingford, CT, USA, 2002; pp. 207-237.

12. Proctor, M.C.; Smirnoff, N. Rapid recovery of photosystems on rewetting desiccation-tolerant mosses: Chlorophyll fluorescence and inhibitor experiments. J. Exp. Bot. 2000, 51, 1695-1704. [CrossRef]

13. Kranner, I.; Birtić, S. A modulating role for antioxidants in desiccation tolerance. Integr. Comp. Biol. 2005, 45, 734-740. [CrossRef]

14. Palmqvist, K. Tansley review No. 117 carbon economy in lichens. New Phytol. 2000, 148, 11-36. [CrossRef]

15. Heber, U. Photoprotection of green plants: A mechanism of ultra-fast thermal energy dissipation in desiccated lichens. Planta 2008, 228, 641-650. [CrossRef] 
16. Komura, M.; Yamagishi, A.; Shibata, Y.; Iwasaki, I.; Itoh, S. Mechanism of strong quenching of photosystem II chlorophyll fluorescence under drought stress in a lichen, Physciella melanchla, studied by subpicosecond fluorescence spectroscopy. Biochim. Biophys. Acta 2010, 1797, 331-338. [CrossRef]

17. Veerman, J.; Vasil'ev, S.; Paton, G.D.; Ramanauskas, J.; Bruce, D. Photoprotection in the lichen Parmelia sulcata: The origins of desiccation-induced fluorescence quenching. Plant Physiol. 2007, 145, 997-1005. [CrossRef] [PubMed]

18. MacKenzie, T.D.; Król, M.; Huner, N.P.; Campbell, D.A. Seasonal changes in chlorophyll fluorescence quenching and the induction and capacity of the photoprotective xanthophyll cycle in Lobaria pulmonaria. Can. J. Bot. 2002, 80, 255-261. [CrossRef]

19. MacKenzie, T.D.; MacDonald, T.M.; Dubois, L.A.; Campbell, D.A. Seasonal changes in temperature and light drive acclimation of photosynthetic physiology and macromolecular content in Lobaria pulmonaria. Planta 2001, 214, 57-66. [CrossRef] [PubMed]

20. Calatayud, A.; Deltoro, V.I.; Barreno, E.; Valle-Tascon, S.D. Changes in in vivo chlorophyll fluorescence quenching in lichen thalli as a function of water content and suggestion of zeaxanthin-associated photoprotection. Physiol. Plant. 1997, 101, 93-102. [CrossRef]

21. Kranner, I.; Cram, W.J.; Zorn, M.; Wornik, S.; Yoshimura, I.; Stabentheiner, E.; Pfeifhofer, H.W. Antioxidants and photoprotection in a lichen as compared with its isolated symbiotic partners. Proc. Natl. Acad. Sci. USA 2005, 102, 3141-3146. [CrossRef]

22. Zorn, M.; Pfeifhofer, H.W.; Grill, D.; Kranner, I. Responses of plastid pigments to desiccation and rehydration in the desert lichen Ramalina maciformis. Symbiosis Rehovot 2001, 31, 201-212.

23. Sancho, L.G.; Pintado, A.; Navarro, F.; Ramos, M.; De Pablo, M.A.; Blanquer, J.M.; Raggio, J.; Valladares, F.; Green, T.G.A. Recent warming and cooling in the Antarctic Peninsula region has rapid and large effects on lichen vegetation. Sci. Rep. 2017, 7, 5689. [CrossRef]

24. Sancho, L.G.; Pintado, A.; Green, T. Antarctic studies show lichens to be excellent biomonitors of climate change. Diversity 2019, 11, 42. [CrossRef]

25. Laguna-Defior, C.; Pintado, A.; Green, T.A.; Blanquer, J.M.; Sancho, L.G. Distributional and ecophysiological study on the Antarctic lichens species pair Usnea antarctica/Usnea aurantiaco-atra. Polar Biol. 2016, 39, 1183-1195. [CrossRef]

26. Barták, M.; Hájek, J.; Očenášová, P. Photoinhibition of photosynthesis in Antarctic lichen Usnea antarctica. I. Light intensity-and light duration-dependent changes in functioning of photosystem II. Czech Polar Rep. 2012, 2, 42-51. [CrossRef]

27. Očenášová, P.; Barták, M.; Hájek, J. Photoinhibition of photosynthesis in Antarctic lichen Usnea antarctica. II. Analysis of non-photochemical quenching mechanisms activated by low to medium light doses. Czech Polar Rep. 2014, 4, 90-99. [CrossRef]

28. Balarinová, K.; Barták, M.; Hazdrová, J.; Hájek, J.; Jílková, J. Changes in photosynthesis, pigment composition and glutathione contents in two Antarctic lichens during a light stress and recovery. Photosynthetica 2014, 52, 538-547. [CrossRef]

29. Olech, M. Lichenological assessment of the Cape Lions Rump, King George Island, South Shetland Islands a baseline for monitoring biological changes. Pol. Polar Res. 1994, 15, 111-130.

30. Olech, M. Annotated Checklist of Antarctic Lichens and Lichenicolous Fungi; Institute of Botany of the Jagiellonian University: Kraków, Poland, 2001; p. 145.

31. Øvstedal, D.O.; Smith, R.L. Lichens of Antarctica and South Georgia: A Guide to Their Identification and Ecology; Cambridge University Press: Cambridge, UK, 2001; p. 411.

32. Stenroos, S. Taxonomy and distribution of the lichen family Cladoniaceae in the Antarctic and peri-Antarctic regions. Cryptogam. Bot. 1993, 3, 310-344.

33. Ahti, T. Cladoniaceae. Flora Neotropica Monograph 78; Organization for Flora Neotropica, New York Botanical Garden: New York, NY, USA, 2000; p. 362.

34. Brodo, I.M.; Sharnoff, S.D.; Sharnoff, S. Lichens of North America; Yale University Press: New Haven, NJ, USA, $2001 ;$ p. 828.

35. Kim, J.H.; Ahn, I.-Y.; Hong, S.G.; Andreev, M.; Lim, K.-M.; Oh, M.J.; Koh, Y.J.; Hur, J.-S. Lichen flora around the Korean Antarctic Scientific Station, King George Island, Antarctic. J. Microbiol. 2006, 44, 480-491. [PubMed]

36. Osyczka, P.; Olech, M. The lichen genus Cladonia of King George Island, South Shetland Islands, Antarctica. Pol. Polar Res. 2005, 26, 107-123. 
37. Park, C.H.; Jeong, G.; Hong, S.G. Possible multiple introductions of Cladonia borealis to King George Island. Antarct. Sci. 2012, 24, 359-366. [CrossRef]

38. Lee, J.S.; Lee, H.K.; Hur, J.-S.; Andreev, M.; Hong, S.G. Diversity of the lichenized fungi in King George Island, Antarctica, revealed by phylogenetic analysis of partial large subunit rDNA sequences. J. Microbiol. Biotechnol. 2008, 18, 1016-1023.

39. Park, C.H.; Kim, K.M.; Elvebakk, A.; Kim, O.S.; Jeong, G.; Hong, S.G. Algal and fungal diversity in Antarctic lichens. J. Eukaryot. Microbiol. 2015, 62, 196-205. [CrossRef]

40. Inoue, T.; Kudoh, S.; Uchida, M.; Tanabe, Y.; Inoue, M.; Kanda, H. Effects of substrate differences on water availability for Arctic lichens during the snow-free summers in the High Arctic glacier foreland. Polar Sci. 2014, 8, 397-412. [CrossRef]

41. Genty, B.; Briantais, J.-M.; Baker, N.R. The relationship between the quantum yield of photosynthetic electron transport and quenching of chlorophyll fluorescence. Biochim. Biophys. Acta 1989, 990, 87-92. [CrossRef]

42. Kranner, I.; Beckett, R.; Hochman, A.; Nash, T.H. Desiccation-Tolerance in Lichens: A Review. Bryologist 2008, 111, 576-593. [CrossRef]

43. Gauslaa, Y.; Solhaug, K.A. Photoinhibition in lichens depends on cortical characteristics and hydration. Lichenologist 2004, 36, 133-143. [CrossRef]

44. Solhaug, K.A.; Gauslaa, Y.; Nybakken, L.; Bilger, W. UV-induction of sun-screening pigments in lichens. New Phytol. 2003, 158, 91-100. [CrossRef]

45. Barták, M.; Gloser, J.; Hájek, J. Visualized photosynthetic characteristics of the lichen Xanthoria elegans related to daily courses of light, temperature and hydration: A field study from Galindez Island, maritime Antarctica. Lichenologist 2005, 37, 433-443. [CrossRef]

46. Lange, O.L.; Green, T.A. High thallus water content severely limits photosynthetic carbon gain of central European epilithic lichens under natural conditions. Oecologia 1996, 108, 13-20. [CrossRef]

47. Demmig-Adams, B.; Máguas, C.; Adams, W.W.; Meyer, A.; Kilian, E.; Lange, O.L. Effect of high light on the efficiency of photochemical energy conversion in a variety of lichen species with green and blue-green phycobionts. Planta 1990, 180, 400-409. [CrossRef]

48. Tyystjärvi, E. Photoinhibition of photosystem II. In International Review of Cell and Molecular Biology; Elsevier: Oxford, UK, 2013; Volume 300, pp. 243-303.

49. Lange, O. Photosynthesis of soil-crust biota as dependent on environmental factors. In Biological Soil Crusts: Structure, Function, and Management; Springer: Heidelberg, Germany, 2001; Volume 150, pp. 217-240.

50. Darrouzet-Nardi, A.; Reed, S.C.; Grote, E.E.; Belnap, J. Observations of net soil exchange of $\mathrm{CO}_{2}$ in a dryland show experimental warming increases carbon losses in biocrust soils. Biogeochemistry 2015, 126, 363-378. [CrossRef]

51. Reiter, R.; Höftberger, M.; Green, T.A.; Türk, R. Photosynthesis of lichens from lichen-dominated communities in the alpine/nival belt of the Alps-II: Laboratory and field measurements of $\mathrm{CO}_{2}$ exchange and water relations. Flora-Morphol. Distrib. Funct. Ecol. Plants 2008, 203, 34-46. [CrossRef]

52. Harris, G.P. The ecology of corticolous lichens: II. The relationship between physiology and the environment. J. Ecol. 1971, 59, 441-452. [CrossRef]

53. Hájek, J.; Barták, M.; Gloser, J. Effects of thallus temperature and hydration on photosynthetic parameters of Cetraria islandica from contrasting habitats. Photosynthetica 2001, 39, 427-435. [CrossRef]

54. Büdel, B.; Scheidegger, C. Thallus morphology and anatomy. Lichen Biol. 1996, 2, 40-68.

55. Lange, O.L. Photosynthetic productivity of the epilithic lichen Lecanora muralis: Long-term field monitoring of $\mathrm{CO}_{2}$ exchange and its physiological interpretation. I. Dependence of photosynthesis on water content, light, temperature, and $\mathrm{CO}_{2}$ concentration from laboratory measurements. Flora-Morphol. Distrib. Funct. Ecol. Plants 2002, 197, 233-249.

56. Lange, O.L. Photosynthetic productivity of the epilithic lichen Lecanora muralis: Long-term field monitoring of $\mathrm{CO}_{2}$ exchange and its physiological interpretation: II. Diel and seasonal patterns of net photosynthesis and respiration. Flora-Morphol. Distrib. Funct. Ecol. Plants 2003, 198, 55-70. [CrossRef]

57. Gasulla, F.; de Nova, P.G.; Esteban-Carrasco, A.; Zapata, J.M.; Barreno, E.; Guéra, A. Dehydration rate and time of desiccation affect recovery of the lichenic algae Trebouxia erici: Alternative and classical protective mechanisms. Planta 2009, 231, 195-208. [CrossRef] [PubMed] 
58. Nabe, H.; Funabiki, R.; Kashino, Y.; Koike, H.; Satoh, K. Responses to desiccation stress in bryophytes and an important role of dithiothreitol-insensitive non-photochemical quenching against photoinhibition in dehydrated states. Plant Cell Physiol. 2007, 48, 1548-1557. [CrossRef]

59. Ralph, P.J.; Gademann, R. Rapid light curves: A powerful tool to assess photosynthetic activity. Aquat. Bot. 2005, 82, 222-237. [CrossRef]

60. Kramer, D.M.; Johnson, G.; Kiirats, O.; Edwards, G.E. New fluorescence parameters for the determination of $\mathrm{Q}$ A redox state and excitation energy fluxes. Photosynth. Res. 2004, 79, 209. [CrossRef]

61. Kooten, O.; Snel, J.F. The use of chlorophyll fluorescence nomenclature in plant stress physiology. Photosynth. Res. 1990, 25, 147-150. [CrossRef]

62. Schreiber, U.; Schliwa, U.; Bilger, W. Continuous recording of photochemical and non-photochemical chlorophyll fluorescence quenching with a new type of modulation fluorometer. Photosynth. Res. 1986, 10, 51-62. [CrossRef]

63. Krause, G.; Vernotte, C.; Briantais, J.-M. Photoinduced quenching of chlorophyll fluorescence in intact chloroplasts and algae. Resolution into two components. Biochim. Biophys. Acta 1982, 679, 116-124. [CrossRef]

64. Krause, G.H.; Jahns, P. Non-photochemical energy dissipation determined by chlorophyll fluorescence quenching: Characterization and function. In Chlorophyll a Fluorescence; Springer: Dordrecht, The Netherlands, 2004; Volume 19, pp. 463-495.

65. Allen, J.F.; Bennett, J.; Steinback, K.E.; Arntzen, C.J. Chloroplast protein phosphorylation couples plastoquinone redox state to distribution of excitation energy between photosystems. Nature 1981, 291, 25. [CrossRef]

66. Krause, G.H. Photoinhibition of photosynthesis. An evaluation of damaging and protective mechanisms. Physiol. Plant. 1988, 74, 566-574. [CrossRef]

67. Quick, W.P.; Stitt, M. An examination of factors contributing to non-photochemical quenching of chlorophyll fluorescence in barley leaves. Biochim. Biophys. Acta 1989, 977, 287-296. [CrossRef]

68. Walters, R.G.; Horton, P. Resolution of components of non-photochemical chlorophyll fluorescence quenching in barley leaves. Photosynth. Res. 1991, 27, 121-133. [CrossRef] [PubMed]

69. Štepigová, J.; Gauslaa, Y.; Cempirkova-Vrablikova, H.; Solhaug, K. Irradiance prior to and during desiccation improves the tolerance to excess irradiance in the desiccated state of the old forest lichen Lobaria pulmonaria. Photosynthetica 2008, 46, 286. [CrossRef]

70. Fernández-Marín, B.; Becerril, J.; García-Plazaola, J. Unravelling the roles of desiccation-induced xanthophyll cycle activity in darkness: A case study in Lobaria pulmonaria. Planta 2010, 231, 1335-1342. [CrossRef]

71. Heber, U.; Lange, O.L.; Shuvalov, V.A. Conservation and dissipation of light energy as complementary processes: Homoiohydric and poikilohydric autotrophs. J. Exp. Bot. 2006, 57, 1211-1223. [CrossRef]

72. Spribille, T.; Tuovinen, V.; Resl, P.; Vanderpool, D.; Wolinski, H.; Aime, M.C.; Schneider, K.; Stabentheiner, E.; Toome-Heller, M.; Thor, G. Basidiomycete yeasts in the cortex of ascomycete macrolichens. Science 2016, 353, 488-492. [CrossRef]

73. Bačkor, M.; Peksa, O.; Škaloud, P.; Bačkorová, M. Photobiont diversity in lichens from metal-rich substrata based on ITS rDNA sequences. Ecotoxicol. Environ. Saf. 2010, 73, 603-612. [CrossRef]

74. Beiggi, S.; Piercey-Normore, M.D. Evolution of ITS ribosomal RNA secondary structures in fungal and algal symbionts of selected species of Cladonia sect. Cladonia (Cladoniaceae, Ascomycotina). J. Mol. Evol. 2007, 64, 528-542. [CrossRef] [PubMed]

75. Cordeiro, L.M.; Reis, R.A.; Cruz, L.M.; Stocker-Wörgötter, E.; Grube, M.; Iacomini, M. Molecular studies of photobionts of selected lichens from the coastal vegetation of Brazil. FEMS Microbiol. Ecol. 2005, 54, 381-390. [CrossRef] [PubMed]

76. Nelsen, M.; Gargas, A. Actin type intron sequences increase phylogenetic resolution: An example from Asterochloris (Chlorophyta: Trebouxiphceae). Lichenologist 2006, 38, 35-440. [CrossRef]

77. Nelsen, M.P.; Gargas, A. Dissociation and horizontal transmission of codispersing lichen symbionts in the genus Lepraria (Lecanorales: Stereocaulaceae). New Phytol. 2008, 177, 264-275. [CrossRef] [PubMed]

78. Peksa, O.; Škaloud, P. Do photobionts influence the ecology of lichens? A case study of environmental preferences in symbiotic green alga Asterochloris (Trebouxiophyceae). Mol. Ecol. 2011, 20, 3936-3948. [CrossRef] 
79. Piercey-Normore, M.D.; De Priest, P.T. Algal switching among lichen symbioses. Am. J. Bot. 2001, 88, 1490-1498. [CrossRef]

80. Skaloud, P.; Peksa, O. Evolutionary inferences based on ITS rDNA and actin sequences reveal extensive diversity of the common lichen alga Asterochloris (Trebouxiophyceae, Chlorophyta). Mol. Phylogenetics Evol. 2010, 54, 36-46. [CrossRef]

81. Škaloud, P.; Steinová, J.; Řídká, T.; Vančurová, L.; Peksa, O. Assembling the challenging puzzle of algal biodiversity: Species delimitation within the genus Asterochloris (Trebouxiophyceae, Chlorophyta). J. Phycol. 2015, 51, 507-527. [CrossRef]

82. Yahr, R.; Vilgalys, R.; Depriest, P.T. Strong fungal specificity and selectivity for algal symbionts in Florida scrub Cladonia lichens. Mol. Ecol. 2004, 13, 3367-3378. [CrossRef]

83. Porcar-Castell, A.; Pfündel, E.; Korhonen, J.F.; Juurola, E. A new monitoring PAM fluorometer (MONI-PAM) to study the short-and long-term acclimation of photosystem II in field conditions. Photosynth. Res. 2008, 96, 173-179. [CrossRef]

84. Doyle, J.J.; Doyle, J.L. A rapid DNA isolation procedure for small quantities of fresh leaf tissue. Phytochem. Bull. 1987, 19, 11-15.

85. White, T.; Bruns, T.; Lee, S.; Taylor, J. Amplification and direct sequencing of fungal ribosomal RNA genes for phylogenetics. In PCR Protocols: A Guide to Methods and Applications; Innis, M.A., Gelfand, D.H., Sninsky, J.J., White, T.J., Eds.; Academic Press, Inc.: San Diego, CA, USA, 1990; pp. 315-322.

86. Sun, W.Q. Methods for the study of water relations under desiccation stress. In Desiccation and Survival in Plants: Drying without Dying; CABI Publishing: Willingford, UK, 2002; pp. 47-91.

(C) 2020 by the authors. Licensee MDPI, Basel, Switzerland. This article is an open access article distributed under the terms and conditions of the Creative Commons Attribution (CC BY) license (http://creativecommons.org/licenses/by/4.0/). 